\title{
HOW DID THE CANADA GOOSE GET ITS NAME BEFORE THERE WAS A CANADA?
}

\section{STUART HOUSTON, 863 University Drive,}

Saskatoon, Saskatchewan. S7N 0J8

The above question was posed by Dr. Bernice Capusten of Red Deer, Alberta. Bernice, a former student of mine and now a radiologist, is the daughter of the late expert in mushrooms and photography, Tony Capusten of Prince Albert, Saskatchewan. ${ }^{1}$ Hers is an inspired question, and the answer becomes quite a history lesson.

Because of a supposed resemblance to the bustard in Europe, the early French explorers, beginning with Cartier in 1635 , called this large goose the outarde. ${ }^{2}$ This was not an apt name, the bustard and the goose being completely unrelated, with different habits, and resembling each other only in size. Later English explorers called it the grey goose or, from its call, the honker.

Strangely, this goose received the name Canada Goose in Carolina, from Mark Catesby (1682-1749). Catesby, the son of John Catesby, a well-to-do magistrate in Sudbury, Suffolk, England, and grandson of Nicholas Jekyll, who had his own botanical garden at nearby Castle Hedingham, spent twelve years (1714-19 and 1722-26) studying the birds of Carolina, adjacent states, and the Bahama Islands. A headand-neck painting of a Canada Goose became Plate 33 in Catesby's magnificent two-volume Natural History of Carolina, Florida, and the
Bahama Islands, the first volume of which appeared in 1729-32. ${ }^{3}$

Of 109 species of birds illustrated by Catesby, 71 were given binomial Latin names by Carl von Linnaeus in 1758. Linnaeus' tenth edition of his Systema Naturae, as Gavin de Beer wrote in the introduction to the 1956 reprint, is "One of the great books in the history of science because it marked the start of an epoch in two essential fields of zoological study: systematics or taxonomy, and nomenclature."4 Linnaeus often used geographic descriptors for his species, such as brasiliensis, bahamensis, carolinus, and lapponicus; he named the goose Branta canadensis. Linnaeus in 1758 greatly extended the area considered as Canada when he used the descriptor canadensis for three species from Hudson Bay: a subspecies each of the Golden Eagle, Sandhill Crane, and Spruce Grouse.

It is not surprising that settled and prosperous Carolina should have been the main geographical source for Linnaeus' new bird species from North America. It is surprising that the second most cited locality was the remote, sparsely settled Hudson Bay region, and even more surprising that Linnaeus was sufficiently forward-thinking to consider Hudson Bay within Canada. James Isham, a Hudson's Bay Company fur trader at 
Hudson Bay, sent specimens to England, and these were figured in another sumptuous and beautifully illustrated book, the four-volume Natural History of Birds, published by George Edwards in London in 1743, 1747,1750 and 1751.

In his third volume (1750), Edwards provided illustrations of the thirteen species that Linnaeus later used as his "type specimens" from Hudson Bay. "Edwards used the Catesby name, Canada Goose, saying that, "They are found in Canada, and are brought also to us from New England and Hudson's-Bay." Edwards clearly differentiated between the localities of Canada and Hudson Bay but in 1758 Linnaeus used canadensis to encompass a wider area that included Hudson Bay. The fifth edition of the Check-List of North American Birds, compiled by the American Ornithologists' Union in 1957, gives "City of Quebec" as the type locality for the Canada Goose, and "Hudson Bay", for the canadensis subspecies of Golden Eagle, Sandhill Crane and Spruce Grouse. ${ }^{6}$

As Bernice suggested, the name "Canada" did not come into official use until 1791, when the Constitutional Act of Canada divided Quebec into the provinces of Upper Canada and Lower Canada. In 1841 they were joined to form the Province of Canada, and in 1867 they were joined with Nova Scotia and New Brunswick to form "One Dominion under the name of Canada."7

The best account of the origin of the name Canada that I have seen is W. Kaye Lamb's entry in The Canadian Encyclopedia, 2nd edition (1988). ${ }^{7}$ Lamb tells us that Canada is derived "from the Huron-Iroquois kanata, meaning a village or settlement."7 On 13 August 1535, Jacques Cartier was told, by two Indian youths he was bringing back from France, that the route "to Canada" lay to the south of Anticosti Island. By "Canada" the two young men meant the village of Stadacona, the site of present Quebec City. Cartier's use of "Riviere de Canada" was followed by Champlain in 1604. (See footnote). Du Creux's book, Historia Canadensis in 1664, used the term Canada to refer to the banks of the river and the Gulf of St. Lawrence. The name came gradually to refer to a more extended area. In 1762, three years after the conquest of Quebec by James Wolfe, General Thomas Gage said that the limits between Canada and Louisiana had never been clearly described. ${ }^{7}$

Yes, Bernice, the name Canada Goose was well established long before Canada became an official name of part of our present country. The legal use of the name Canada, however, was but official recognition of the name that had, since 1535 , been widely used to describe an ever-enlarging area that centred on the St. Lawrence River basin.

1. HOUSTON, C.S. 1988. Tony Capusten (1915-1987). Blue Jay 46:3-4.

2. AVIS, W.S., editor-in-chief. 1967. The dictionary of Canadian English: a dictionary of Canadianisms on historical principles. W.J. Gage, Toronto. $531 \mathrm{pp}$.

3. CATESBY, M. The natural history of Carolina, Florida, and the Bahama Islands. Published privately, London.

4. LINNAEUS, C. 1758 , reprinted 1956. Systema Naturae, Regnum Animale. (Tenth ed.) British Museum (Natural History), London.

5. EDWARDS, G. 1750. A natural history of uncommon birds. Published privately, London.

6. AMERICAN ORNITHOLOGISTS' UNION. 1957. Check-List of North American Birds. (Fifth ed.) Lord Baltimore Press, Baltimore. 328 pp. 


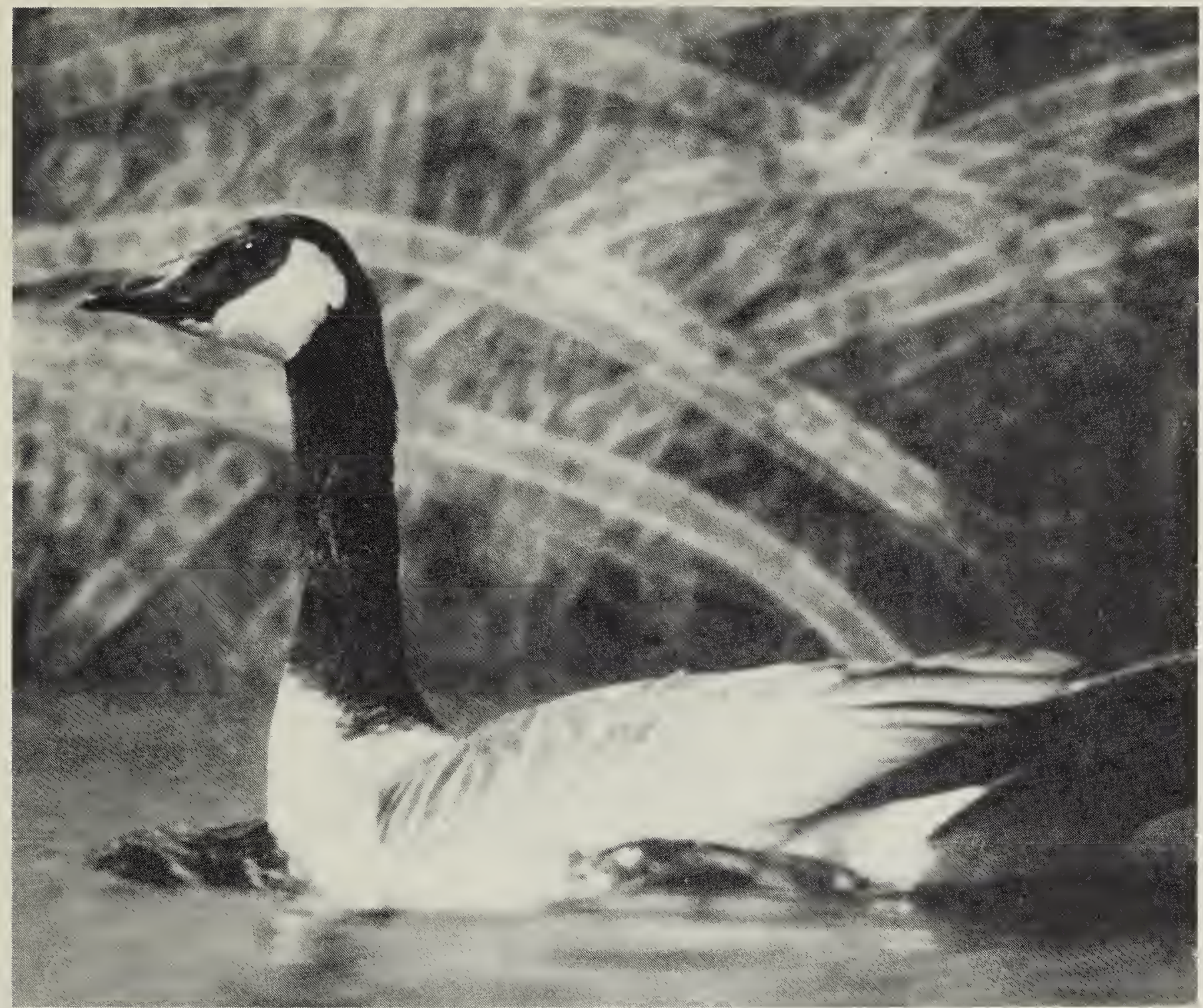

Ken Lumbis

7. LAMB, W.K. 1988. Canada, pp.1:322 in: The Canadian encyclopedia. (Second ed.) Edmonton: Hurtig.

Footnote: The Dictionary of Canadian English: A Dictionary of Canadianisms on Historical Principles, under the entry Canada, states clearly that, "The etymology of Canada is by no means clearly established. During the past three hundred years many solutions of the problem have been offered, most of them fanciful." ${ }^{2}$ In addition to the generally accepted explanation given by Kaye Lamb, and the similar explanation of "village dwellers" given by Barbeau in 1954, the more fanciful examples include:

"Aca nada," here is nothing (Jefferys, 1754);

"Can," mouth, and "Ada," the country
(Jefferys, 1760);

"Monsieur Cane," who sailed into the country (Nova Scotia Magazine, 1789);

"Capa di nada," Cape Nothing (Long, 1791);

"Can a day," a can of spruce beer a day (Kingston Gazette, 1811);

"Canara" and "Carnata," because land was taken to be a portion of southern India (Canadian Naturalist, 1861);

"Kanatats," they are strangers, said by the natives when the saw the first Europeans (Chambers, 1896);

and a Spanish word meaning gutter, (Victoria Daily Colonist, 1964). 